\title{
Multi-scale Influence of Snowmelt on Xylogenesis of Black Spruce
}

\author{
Sergio Rossi*† \\ Hubert Morin* and \\ Annie Deslauriers* \\ *Département des Sciences \\ Fondamentales, Université du Québec à \\ Chicoutimi, 555 Boulevard de \\ l'Université, Chicoutimi (QC), G7H2B1, \\ Canada \\ $\dagger$ Corresponding author: \\ sergio.rossi@uqac.ca
}

\begin{abstract}
Snowmelt is considered to affect growth of the boreal forest. So, we tested the hypothesis that late snowmelts delay the onset of xylogenesis and reduce xylem production in trees. Timings of xylem formation were compared to the dates of complete snowmelt combining a 7-year monitoring of cambial activity with meteorological records in four plots of Picea mariana in Quebec, Canada. The spatial and temporal variability in snowfall was analyzed separately, so taking into account both the long- and short-term effects. Snowfall occurred from October to May, with a snow cover lasting 173-199 days. Overall, xylogenesis lasted 99117 days, with onsets ranging from late May to mid-June. The highest cell productions were observed in the warmest site, where the longest periods of growth were observed. Although at long-term the effects of snowmelt were significant for both onset and duration of xylogenesis and cell production, at short-term only the relationship between the onset of xylogenesis and the date of complete snowmelt was significant. The initial hypothesis could be confirmed only partially. The different responses to the long- and short-term analyses demonstrate the multi-scale influence of snowfall on tree growth and the determinant role of nutrient cycling in the productivity of boreal ecosystems.
\end{abstract}

\section{Introduction}

In the boreal forest, the alternating winter-summer succession of favorable and adverse climatic conditions leads to a pulsing growth, which irreversibly marks the wood of trees with annual rings. In most regions with cold climates, the soil is frozen or covered by snow in winter, with temperatures close to $0{ }^{\circ} \mathrm{C}$. At these temperatures, metabolism slows down as much as possible because only minimal physiological activity is allowed (Decker et al., 2003; Körner, 2003b; Rossi et al., 2008b). Several studies have reported that, where temperature limits tree growth, the upper soil layer must start to thaw before radial growth can resume (Graumlich and Brubaker, 1986; Cairns and Malanson, 1998). However, neither the control mechanisms (e.g. gradual influences versus threshold effects) nor the physiological processes (e.g. carbon assimilation versus allocation) involved in the limiting effect of low temperatures have yet been clearly and definitively demonstrated for growth (Körner, 2003a). It is assumed that soils at temperatures close to or below $0{ }^{\circ} \mathrm{C}$ inhibit root activity and water uptake. Thus cambium, which has synchronous activity in stem and roots (Thibeault-Martel et al., 2008), begins to divide only after the snow disappears and soil begins to warm up (Rossi et al., 2007; Turcotte et al., 2009; Lupi et al., 2010).

Cell production is closely interconnected with the phenological phases of xylem according to causal links. The date of onset of xylogenesis affects the number of cells produced by the cambium which, in turn, influences the ending of cell differentiation (Lupi et al., 2010). As a result, earlier cambial resumptions lengthen the period available for cell division in the secondary meristem, increasing the growth potential during the year (Gričar et al., 2005; Rossi et al., 2007, 2008a; Deslauriers et al., 2008). Also, in conifers the higher amount of cells produced by cambium leads to larger accumulations of cells in the developing xylem, increasing the time spent differentiating and maturing the tracheids and delaying the ending of wood formation (Lupi et al., 2010). Based on this causal relationship, it is assumed that a climatic factor affecting the date of resumption of growth could indirectly influence cell production.

High air temperatures promote earlier snowmelt, making water rapidly available to the roots for stem rehydration and photosynthesis, and allowing the temperature in the upper layer of soil to rise (Goodine et al., 2008; Turcotte et al., 2009). High spring temperatures could also affect cambial activity by increasing the rate of cell division and the amount of xylem produced (Deslauriers and Morin, 2005). However, despite the marked increasing trend of temperatures detected at northern latitudes, a tree-ring and climate analysis in subarctic Eurasia showed a tendency towards reduced growth in conifers. The observed thinner tree rings have been linked by Vaganov et al. (1999) to a significant increase in snowfall that should have delayed the date of complete snowmelt and, consequently, growth resumption in spring.

In the coming century, the ecosystems at high latitudes are projected to experience the greatest rates of warming, and will be locally associated with increases in winter precipitation (Serreze et al., 2000; Zhang et al., 2000). Although the potential effects of warming on growth in temperature-limited environments with adequate water availability are known (Chen et al., 1999; Menzel et al., 2006; McMillan et al., 2008; Rossi et al., 2011), the influence of snowfall on the phenology and production of trees is less clear. Since the assumptions of the long-term trend in winter precipitation and date of snowmelt reported by Vaganov et al. (1999) were based on statistical models rather than on direct observations, the relationship linking snowmelt with the timings and production of xylem remains an intriguing but an as-yet unproved hypothesis.

It has been argued that the length of the snow-free period indirectly influences tree growth by acting on the carbon dioxide 
uptake and nutrient cycling and availability (Jarvis and Linder, 2000). However, the effect of spring temperatures on soil decomposition and mineralization is likely to be delayed until summer, when the production of new cells by cambium is concluded, and to cumulate in time, becoming apparent only in the long term (Bergh et al., 1999). At the heart of the question lies the need to disentangle the direct and indirect effects of meteorological factors on cambial phenology and cell production in xylem. However, the available investigations on intra-annual growth are limited in space and time, which invalidates any deductions on wide temporal scales. This study compared the intra-annual dynamics of xylem formation with the dates of complete snowmelt combining a 7-year monitoring of cambial activity with meteorological records in four permanent plots of black spruce [Picea mariana (Mill.) B.S.P.] in the boreal forest of Quebec, Canada. The aim was to test the hypothesis proposed by Vaganov et al. (1999) that late snowmelts delay the onset of xylogenesis and reduce xylem production in trees. To verify the multi-scale influence of snowfall, spatial and temporal variability was analyzed separately in models using year and site as covariates, so taking into account the long- and short-term effects, respectively (Jonas et al., 2008). The long-term effect of snowmelt was represented by spatial variability between the four sites located along an alti-latitudinal gradient. Its short-term effect was represented by the temporal variability in the dates of complete snowmelt and cambial phenology observed during the seven years of monitoring.

\section{Material and Methods}

\section{STUDY AREA AND TREE SELECTION}

The study was conducted on black spruce in the SaguenayLac-Saint-Jean area, in the boreal forest of Quebec, Canada (Fig. 1). The region has a gently rolling topography with hills reaching 500-700 $\mathrm{m}$ a.s.l. on thick and undifferentiated glacial till deposits. Four sites (Simoncouche [abbreviated as SIM], Bernatchez [BER], Mistassibi [MIS], and Camp Daniel [DAN]) were identified in mature even-aged black spruce stands at different altitudes and latitudes to obtain a range in the dynamics of tree growth as wide as possible and to select stands where the absence of evidence of human impact assured that trees had developed under the influence of natural disturbances only (Table 1). In each site, the dominant or co-dominant 120- to 140-year-old trees with upright stems and similar growth rates were chosen (Table 1). Trees with polycormic stems, partially dead crowns, reaction wood, or evident damage due to parasites were avoided.

\section{XYLEM SAMPLING AND PREPARATION}

In each site, tree-ring formation was studied from April to October during 2002-2008 in 5 (2002-2005) and 10 (2006-2008) trees. The increase in the sample size during 2006-2008 was performed to improve accuracy and representativeness of the results. Wood microcores were collected weekly following a spiral trajectory on the stem from $30 \mathrm{~cm}$ below to $30 \mathrm{~cm}$ above breast height $(1.3 \mathrm{~m})$ using surgical bone sampling needles in 2002-2006 and Trephor in 2007-2008 (Rossi et al., 2006a). From 21 to 26 microcores were collected annually from each tree, depending on the site and year. The very small wounds inflicted by the thin piercing tubes of the tools and the consequently narrow areas of traumatized tissues around the sampling points (within a circumference of about $1 \mathrm{~cm}$ around the hole [Forster et al., 2000]) allowed repeated samplings by microcore extraction.

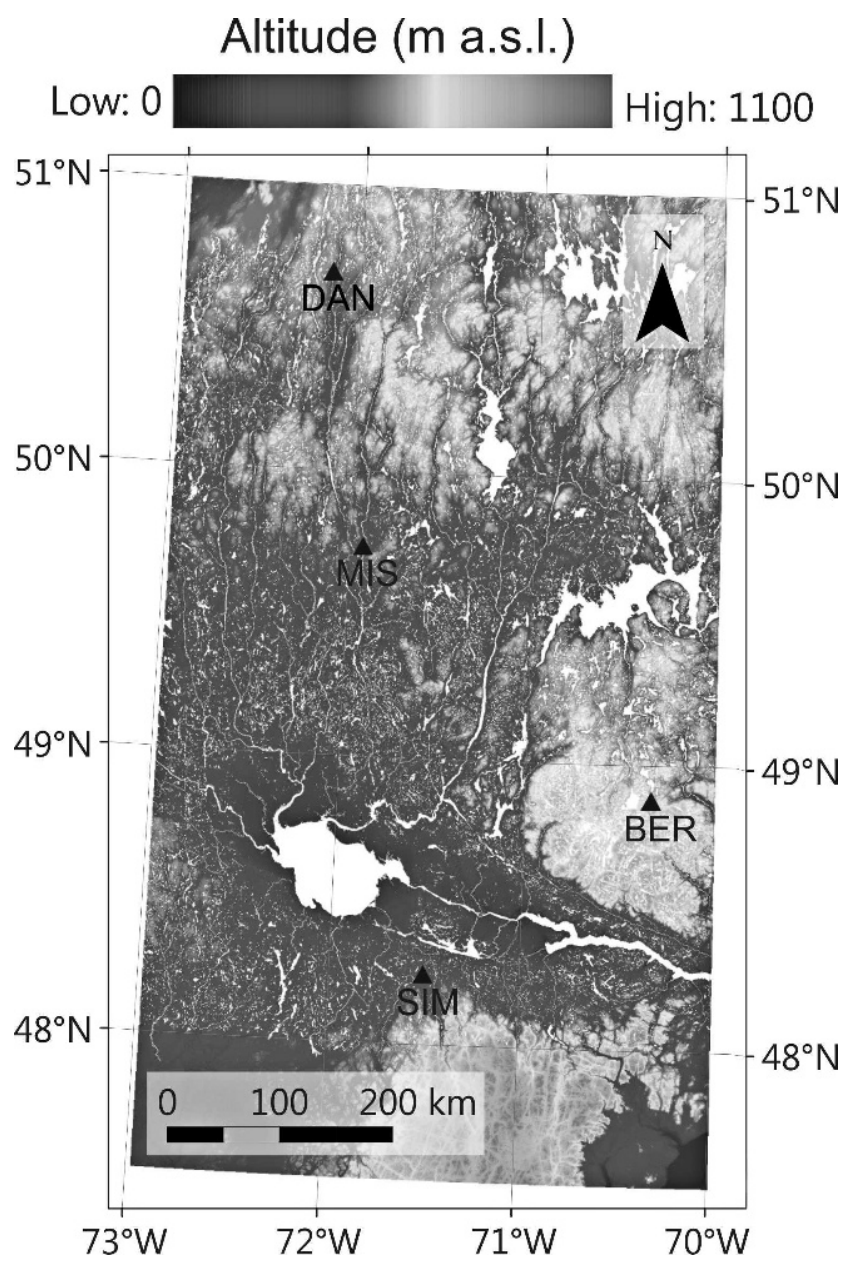

FIGURE 1. Topography of the study area and location of the four permanent plots in Quebec, Canada.

Samples usually contained the previous 4 or 5 tree rings and the developing annual layer with the cambial zone and adjacent phloem. Samplings were performed on the same tree for not more than 4-5 years and wood samples were always taken at least $5 \mathrm{~cm}$ apart to avoid getting resin ducts on adjacent cores. The disturbance reaction of the xylem to the wound spreading to adjacent samples only occurred occasionally as, on average, only 17 sections per year showed tangentially oriented clusters of resin ducts in the developing tree ring.

The microcores were placed in Eppendorf microtubes with an ethanol solution ( $10 \%$ in water) and stored at $5{ }^{\circ} \mathrm{C}$ to avoid tissue deterioration. Microcores were oriented by marking the transverse side with a pencil under a stereomicroscope at magnifications of 10-20×, dehydrated with successive immersions in ethanol and Dlimonene, and embedded in paraffin (Rossi et al., 2006a). Transverse sections of $6-10 \mu \mathrm{m}$ thickness were cut from the samples with a rotary microtome. The sections were stained with cresyl violet acetate $(0.16 \%$ in water $)$ and examined within 10 25 minutes under visible and polarized light at magnifications of $400-500 \times$ to differentiate the developing and mature xylem cells.

\section{MICROSCOPIC OBSERVATIONS}

In each sample, the radial number of cells in the cambial zone, radial enlargement phase, cell wall thickening phase, and mature cells were counted along three radial rows. Rows with cells with large tangential sizes were selected to ensure that only cells cut at 
TABLE 1

Location of the four study sites and characteristics of the sampled trees. Data are reported as mean \pm standard deviation. Diameter at breast height $=\mathrm{DBH}$. The number of cells represents the average and variability between the seven study years.

\begin{tabular}{|c|c|c|c|c|c|c|c|}
\hline \multirow[b]{2}{*}{ ID } & \multirow[b]{2}{*}{ Site } & \multicolumn{3}{|c|}{ Site location } & \multicolumn{3}{|c|}{ Tree characteristics } \\
\hline & & Latitude $(\mathrm{N})$ & Longitude (W) & Altitude ( $\mathrm{m}$ a.s.1.) & Height (m) & $\mathrm{DBH}(\mathrm{cm})$ & Cells in the tree ring \\
\hline SIM & Simoncouche & $48^{\circ} 13^{\prime}$ & $71^{\circ} 15^{\prime}$ & 338 & $15.8 \pm 1.6$ & $19.8 \pm 2.2$ & $32.5 \pm 5.1$ \\
\hline BER & Bernatchez & $48^{\circ} 51^{\prime}$ & $70^{\circ} 20^{\prime}$ & 611 & $17.5 \pm 1.9$ & $21.2 \pm 3.3$ & $19.7 \pm 1.9$ \\
\hline MIS & Mistassibi & $49^{\circ} 43^{\prime}$ & $71^{\circ} 56^{\prime}$ & 342 & $18.2 \pm 1.0$ & $20.8 \pm 3.0$ & $17.5 \pm 3.2$ \\
\hline DAN & Camp Daniel & $50^{\circ} 41^{\prime}$ & $72^{\circ} 11^{\prime}$ & 487 & $16.4 \pm 1.9$ & $19.1 \pm 3.0$ & $17.3 \pm 2.7$ \\
\hline
\end{tabular}

their middle longitudinal part were considered. In cross section, cambial cells were characterized by thin cell walls and small radial diameters (Rossi et al., 2006b). The dormant cambium was composed of 4-5 closely spaced cells. At the onset of cambial activity, the cambial zone began to widen rapidly (within a week) as the number of cells increased, revealing that cell division had started. During cell enlargement, the tracheids were composed of a protoplast still enclosed in the thin primary wall but with radial diameter at least twice that of a cambial cell. Deformed rows of tracheids were frequently observed in this phase, due to the enlargement process occurring despite strong compression between xylem tissues and bark. Observations under polarized light discriminated between enlarging and cell-wall-thickening tracheids. Because of the arrangement of cellulose microfibrils, the developing secondary walls shone when observed under polarized light. Instead, no glistening was observed in enlargement zones where the cells were still composed of just primary wall (Abe et al., 1997). The progress of cell wall lignification was detected with cresyl violet acetate reacting with the lignin (Rossi et al., 2006b). Lignification was shown by a color change from violet to blue. The color change over the whole cell wall revealed the end of lignification and the tracheid reaching maturity (Gričar et al., 2005).

The cell number in the 3 rows was averaged for each tree and used to assess onset and ending of xylogenesis. In spring, when at least one horizontal row of cells was observed in the enlargement, xylem formation was considered to have begun. In late summer, when no further cell was observed in wall thickening and lignification, xylem formation was considered complete. The duration of xylogenesis was assessed as the number of days occurring between onset and ending of xylogenesis and was calculated as an average among trees for each studied site and year.

\section{TEMPERATURE AND SNOW MONITORING}

In each site, a standard weather station was installed in a forest gap to measure air and soil temperature and snow depth. The soil temperature was measured in both the organic and mineral layers, at $5-10$ and $20-30 \mathrm{~cm}$ depth, respectively. Snow depth was measured with an acoustic distance sensor that quantified the elapsed time between emission and return of an ultrasonic pulse and automatically corrected for variations of the speed of sound during the year using the measurements of air temperature. Data were collected every 15 minutes and recorded as averages every hour by means of CR10X dataloggers (Campbell Scientific Corporation, Canada). Daily mean values were later calculated with the time series obtained from the 24 measurements per day.

\section{STATISTICAL ANALYSES}

Data from snow depth were converted in a dummy variable, where the values 1 and 0 designated presence and absence of snow, respectively. The relationships between onset and duration of xylogenesis and cell production (response variables) and date of complete snowmelt (regressor) were assessed through analysis of covariance (ANCOVA) using the software package SAS version 9.2 (SAS Institute, Cary, North Carolina). The long- and shortterm effects of snowmelt were taken into account by analyzing the spatial and temporal variability using year and site as covariates, respectively.

\section{Results}

\section{CLIMATIC CHARACTERISTICS OF THE SITES}

The region has a typical boreal climate with very cold winters and cool summers. In the four study sites, the mean annual temperature varied between -1.2 and $1.9{ }^{\circ} \mathrm{C}$, and the MaySeptember temperature varied between 11 and $13.3{ }^{\circ} \mathrm{C}$, with the highest values recorded in 2006 (Table 2). All sites had long winters with mean temperatures close to or below zero for a period ranging between 180 and 230 days and with mean monthly temperatures dropping as low as $-20{ }^{\circ} \mathrm{C}$ in January (data not shown). The coldest months showed absolute minimum temperatures between -34.8 and $-41.5^{\circ} \mathrm{C}$, while summers were generally short with absolute maximum temperatures reaching $32.3{ }^{\circ} \mathrm{C}$. The temperature pattern was related to both latitude and altitude, with the sites located at the higher altitudes (BER and DAN) being the coldest on average.

\section{SNOW AND SOIL TEMPERATURE PATTERNS}

Different temperatures were observed between the two soil layers in the four sites, especially in SIM and BER. In winter, the temperature of the organic layer varied between -1 and $1{ }^{\circ} \mathrm{C}$, while temperatures up to $3{ }^{\circ} \mathrm{C}$ were recorded for the mineral layer (Fig. 2). In spring, complete snowmelt was followed by an abrupt increase in soil temperature, occurring after a few days in DAN, and after three weeks in SIM. The pattern of soil temperatures in summer and early autumn followed that of the air temperature but with lower daily and seasonal variations, in particular for the mineral layer. With the beginning of snow accumulation, soil temperatures gradually decreased to values around $0{ }^{\circ} \mathrm{C}$ (Fig. 2).

In all sites, snow cover lasted 173-199 days (Fig. 2). On average, snow began to accumulate on the ground between the end of October and beginning of November, although large variations were recorded during the monitoring, with snow appearing between mid-October and the beginning of December (Fig. 3). In spring, snowmelt occurred irregularly but proceeded rapidly and, once started, complete snowmelt was concluded throughout the site within one week. This period corresponded to the sampling interval used for the monitoring of tree growth. Complete snowmelt was observed between the beginning of May in SIM, and the end of May in BER and DAN. The maximum snow 
TABLE 2

Climatic characteristics of the four study sites in the boreal forest of Quebec, Canada. Data are based on weather measurements covering the study period 2002-2008.

\begin{tabular}{|c|c|c|c|c|c|}
\hline \multirow[b]{2}{*}{ ID } & \multirow[b]{2}{*}{ Site } & \multicolumn{2}{|c|}{ Mean air temperature } & \multicolumn{2}{|c|}{ Absolute annual air temperature } \\
\hline & & Annual $\left({ }^{\circ} \mathrm{C}\right)$ & May-September $\left({ }^{\circ} \mathrm{C}\right)$ & Maximum $\left({ }^{\circ} \mathrm{C}\right)$ & Minimum $\left({ }^{\circ} \mathrm{C}\right)$ \\
\hline SIM & Simoncouche & 1.9 & 13.3 & 32.3 & -34.8 \\
\hline BER & Bernatchez & 0.2 & 11.4 & 30.3 & -36.2 \\
\hline MIS & Mistassibi & 0.7 & 12.8 & 31.6 & -36.0 \\
\hline DAN & Camp Daniel & -1.2 & 11.0 & 31.6 & -41.5 \\
\hline
\end{tabular}

depths were reached in March, with up to $154 \mathrm{~cm}$ in BER, and followed the same pattern observed for snowmelt, with the sites located at higher latitudes and altitudes accumulating more snow on the ground (Fig. 3).

\section{XYLOGENESIS}

Overall, the onset of xylogenesis occurred from late May to mid-June (DOY 146-169), covering a range of more than 20 days (Fig. 4). Later onsets of xylem growth were observed in the two colder sites, BER and DAN. In average, the variation between years was 15 days, with the maximum value attaining 18 days in DAN. Xylogenesis lasted 99-117 days on average; SIM clearly had the longest duration, attaining 122 days. The number of cells along the tree ring (cell production) differed according to site
(Fig. 4). The highest cell productions were observed in SIM, where the longest periods of growth were observed, with values ranging from 27.3 to 40.1 in 2006 and 2004, respectively. The fewest cells were produced in MIS and DAN, where an average of 17.4 tracheids were counted along the tree ring. MIS and DAN showed the lowest inter-annual variations in cell numbers, while the highest variability was observed in SIM.

\section{SPATIAL VARIABILITY}

The long-term effect of snowmelt was represented by the spatial variability that used the year as covariate in analysis of covariance (ANCOVA). The models were significant for both onset and duration of xylogenesis and cell production with the effect of the date of complete snowmelt revealing $p$-values $<0.0001$

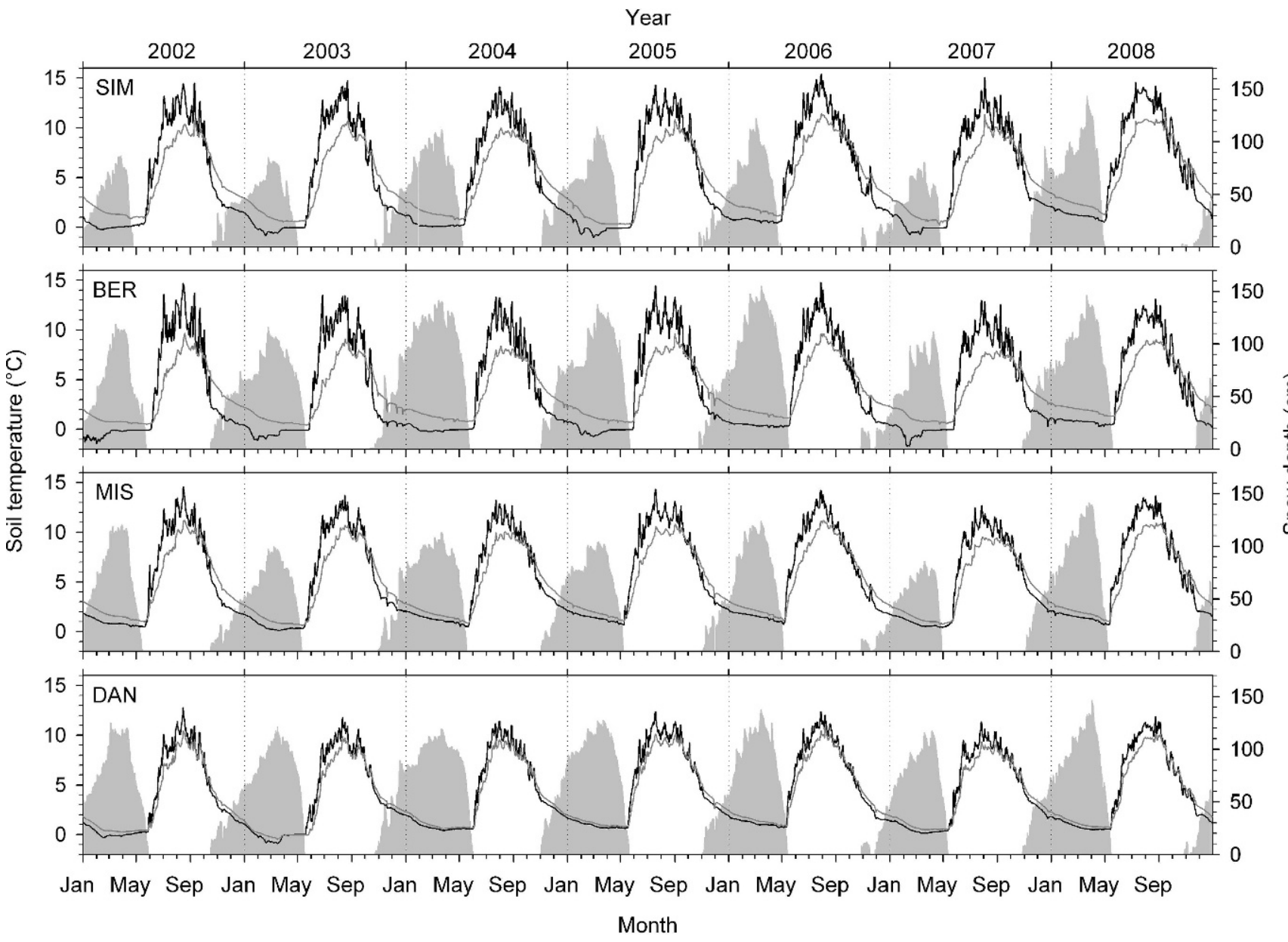

FIGURE 2. Mean daily soil temperatures of the organic (black line) and mineral (dark gray line) layers and snow depth (light gray area) recorded during 2002-2008 in the four permanent plots in Quebec, Canada. SIM = Simoncouche, BER = Bernatchez, MIS = Mistassibi, and DAN = Camp Daniel. 

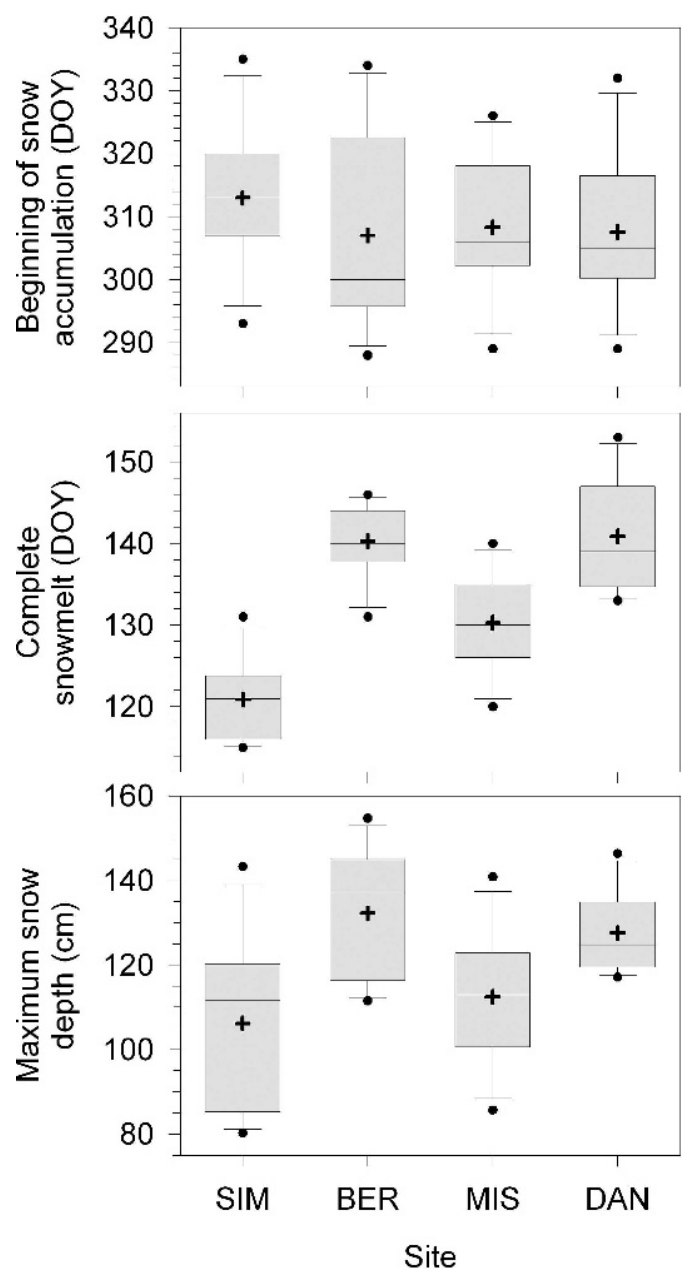

FIGURE 3. Distribution of dates of beginning of snow accumulation and complete snowmelt, and maximum snow depth recorded during 2002-2008 in the four permanent plots in Quebec, Canada. Boxes represent upper and lower quartiles, whiskers achieve the 10th and 90th percentiles, and the mean and median are drawn as cross and horizontal solid lines, respectively. Dots indicate the minimum and maximum observed value.

for all response variables (Table 3). Onset and duration of xylogenesis differed between the seven study years as shown by the significant F-values of 19.52 and 3.77, respectively. Although the date of complete snowmelt affected cell production, no difference was observed for this response variable between years $(\mathrm{F}$-value $=1.43, p>0.05)$. No significant interaction year $\times$ date of complete snowmelt was observed for the three response variables.

\section{TEMPORAL VARIABILITY}

The short-term effect of snowmelt was investigated by analyzing the temporal variability with the variable site used as covariate in ANCOVA. The relationship between the onset of xylogenesis and the date of complete snowmelt found with the longterm effect was confirmed (Table 4). The effect of snowmelt on the onset of xylogenesis was significant $(\mathrm{F}$-value $=15.61, p<0.001)$, while no difference was observed between sites $(\mathrm{F}$-value $=1.01, p>$ 0.05). By plotting both variables together, a positive trend with parallel regression lines was evident in all sites, except in SIM, which showed a regression with a lower slope because of one outlier (Fig. 5). The ANCOVA models performed with the duration of
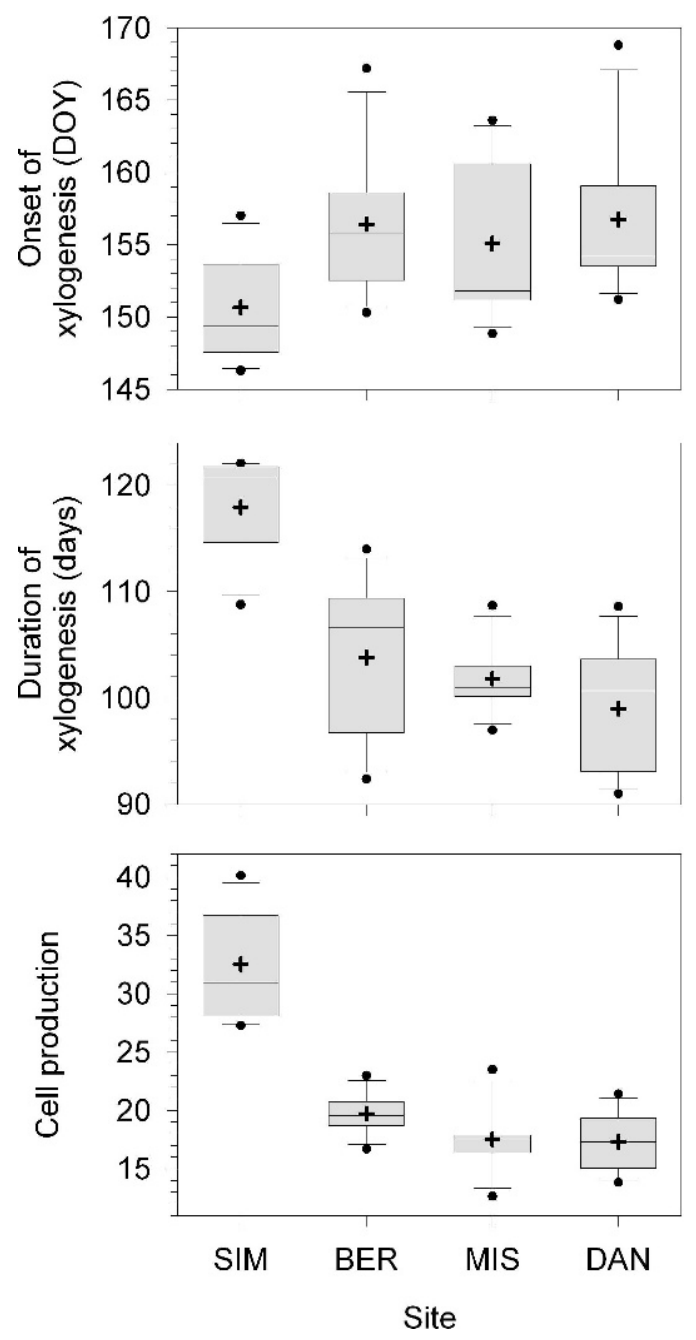

FIGURE 4. Distribution of onset and duration of xylogenesis and cell production (number of cells along the tree ring) in black spruce observed during 2002-2008 in the four permanent plots in Quebec, Canada. Boxes represent upper and lower quartiles, whiskers achieve the 10th and 90th percentiles and the mean and median are drawn as cross and horizontal solid lines, respectively. Dots indicate the minimum and maximum observed value.

xylogenesis and cell production were significant ( $\mathrm{F}$-values of 9.98 and 22.36, respectively, and $p<0.0001$ ). However, the differences were mainly observed between sites, with SIM being the one that differed most from the others (Table 4). Instead, as shown in Figure 5, the regressions of each site had slopes that were not significant $(p>0.05)$, which indicated no significant effect of snowmelt on the duration of xylogenesis and cell production at short term. No significant interaction site $\times$ date of complete snowmelt was observed for the three response variables.

\section{Discussion}

In this study, the hypothesis that late snowmelts delay the onset of xylogenesis and reduce xylem production in trees was tested by combining a 7-year monitoring of cambial activity with measurements of temperature and snow depth in four permanent plots of the boreal forest of Quebec. Data analyses investigated spatiotemporal variability in cambial phenology reflecting (i) the long-term climate-driven features of the different sites, and (ii) the growth responses of the trees to the inter-annual variation in snowmelt. Most statistically significant findings were produced by 
TABLE 3

Between-sites analysis by ANCOVA models performed between onset and duration of xylogenesis and cell production (number of cells along the tree ring) of black spruce (response variable) and date of complete snowmelt (regressor, calculated in DOY) recorded during 2002-2008 in four permanent plots in Quebec (Canada) using year as covariate. Non-significant (NS) indicates a probability $>0.05$.

\begin{tabular}{|c|c|c|c|c|c|c|c|}
\hline \multirow[b]{2}{*}{ Response variable } & \multirow[b]{2}{*}{ Source } & \multicolumn{3}{|c|}{ Regressors } & \multicolumn{3}{|c|}{ Model } \\
\hline & & Type III SS & F-value & $P$ & F-value & $P$ & $\mathrm{R}^{2}$ \\
\hline \multirow[t]{2}{*}{ Onset of xylogenesis } & Date of snowmelt & 174.34 & 50.88 & $<0.0001$ & 33.07 & $<0.0001$ & 0.92 \\
\hline & Year & 401.24 & 19.52 & $<0.0001$ & & & \\
\hline \multirow{2}{*}{$\begin{array}{l}\text { Duration of } \\
\text { xylogenesis }\end{array}$} & Date of snowmelt & 1105.02 & 27.13 & $<0.0001$ & 5.46 & $<0.01$ & 0.65 \\
\hline & Year & 920.44 & 3.77 & $<0.05$ & & & \\
\hline \multirow[t]{2}{*}{ Cell production } & Date of snowmelt & 702.49 & 21.77 & $<0.001$ & 3.32 & $<0.05$ & 0.53 \\
\hline & Year & 276.82 & 1.43 & NS & & & \\
\hline
\end{tabular}

the former rather than the latter analysis, indicating that the influence of snowmelt on tree growth is dependent on the time scale considered by the investigation. In particular, results from the long-term analysis clearly showed that onset and duration of xylogenesis and cell production were strongly correlated with the dates of complete snowmelt, confirming the hypothesis proposed by Vaganov et al. (1999). Instead, the short-term analysis found significant relationships only between onset of xylogenesis and date of complete snowmelt, while no significant result was observed with duration of xylogenesis and cell production.

Our results demonstrated that late snowmelts corresponded to delayed resumptions of cambial activity and cell production (i.e. radial growth) in trees. In spring, the insulating properties of snow prevent the soil from warming up and maintain roots at a constant temperature of around $0{ }^{\circ} \mathrm{C}$, which is below the minimum threshold for growth (Decker et al., 2003; Körner, 2003a; Körner and Hoch, 2006). Only after the snow has completely disappeared does soil temperature increase abruptly and cambium activate its irreversible process of cell division, which will stop only in midsummer (Rossi et al., 2008b). In fact, in cold environments xylem formation occurs commonly during one uninterrupted and short lapse of time (Rossi et al., 2008b). This behavior diverges from other metabolic activities in trees. Needles of evergreen conifers can be temporarily active, showing photosynthetic activity and producing photoassimilates during the warmest days of winter and early spring if liquid water is available for roots (Bergh and Linder, 1999; Goodine et al., 2008).

Whether snowmelt and the increase in soil temperature directly trigger growth still remains an open question. A multitude of variables affects the temperature of soil in spring, such as the amount of winter snowfall, the occurrence of late frosts or rain, and, principally, air temperature. Körner and Paulsen (2004) estimated the growing period of treeline trees by counting the days when the soil temperature at a depth of $10 \mathrm{~cm}$ exceeded $3.2{ }^{\circ} \mathrm{C}$, which in the spring corresponded to a weekly mean canopy temperature of $0{ }^{\circ} \mathrm{C}$. In contrast to the southfacing site, the 1-2 weeks of delayed snowmelt and soil thaw observed in the north-facing site corresponded to later cambial resumptions in trees of the alpine timberline (Rossi et al., 2007). However, different soil temperatures were observed between the two expositions at the beginning of growth, thus suggesting that soil temperature could not be the main limiting factor for cambial resumption (Rossi et al., 2007). In contrast, air and stem temperature better explained the difference between expositions and species, demonstrating that a minimum threshold of temperature had to be reached to sustain xylogenesis. In Rossi et al. (2007), stem temperature represented the thermal conditions in cambium, where xylogenesis occurs, also demonstrating the direct effect of the temperature on the metabolic activities of xylem cells. Furthermore, manipulating experiments heating the stem were able to induce localized reactivation of the cambium (Oribe et al., 2001, 2003; Gričar et al., 2006). Thus, although it is not possible to draw definitive conclusions from this clear but indirect evidence, we deduce that snow and soil temperature act mainly as a covariate of air temperature and would play only a marginal role in growth resumption. In this work, the monitoring of snow depth was performed in a forest gap close to the sampled trees, but with microclimatic conditions that can partially diverge from those occurring under the canopy. The well-known spatial variability of the processes of snowmelt and wood production urgently requires more conclusive individualbased investigations.

The contrasting responses of duration of xylogenesis and cell production to snowmelt indicated an influence of the time scale considered. At a short time scale (temporal variability), extreme but punctual events of delayed snowmelts corresponded to late cambial resumptions but not inevitably to reduced growth. At these latitudes cambial activity lasts at least two months and high rates of cambial activity could still occur during warm and favorable days in late June and July, leading to increased

TABLE 4

Between-years analysis by ANCOVA models performed between onset and duration of xylogenesis and cell production (number of cells along the tree ring) of black spruce (response variable) and date of complete snowmelt (regressor, calculated in DOY) recorded during 2002-2008 in four permanent plots in Quebec (Canada) using site as covariate. Non-significant (NS) indicates a probability $>0.05$.

\begin{tabular}{|c|c|c|c|c|c|c|c|}
\hline \multirow[b]{2}{*}{ Response variable } & \multirow[b]{2}{*}{ Source } & \multicolumn{3}{|c|}{ Regressors } & \multicolumn{3}{|c|}{ Model } \\
\hline & & Type III SS & F-value & $P$ & F-value & $P$ & $\mathrm{R}^{2}$ \\
\hline \multirow[t]{2}{*}{ Onset of xylogenesis } & Date of snowmelt & 281.70 & 15.61 & $<0.001$ & 6.19 & $<0.01$ & 0.51 \\
\hline & Site & 54.70 & 1.01 & NS & & & \\
\hline \multirow{2}{*}{$\begin{array}{l}\text { Duration of } \\
\text { xylogenesis }\end{array}$} & Date of snowmelt & 7.61 & 0.20 & NS & 9.98 & $<0.0001$ & 0.63 \\
\hline & Site & 867.62 & 7.67 & $<0.01$ & & & \\
\hline \multirow[t]{2}{*}{ Cell production } & Date of snowmelt & 0.67 & 0.05 & NS & 22.36 & $<0.0001$ & 0.79 \\
\hline & Site & 636.73 & 17.10 & $<0.0001$ & & & \\
\hline
\end{tabular}



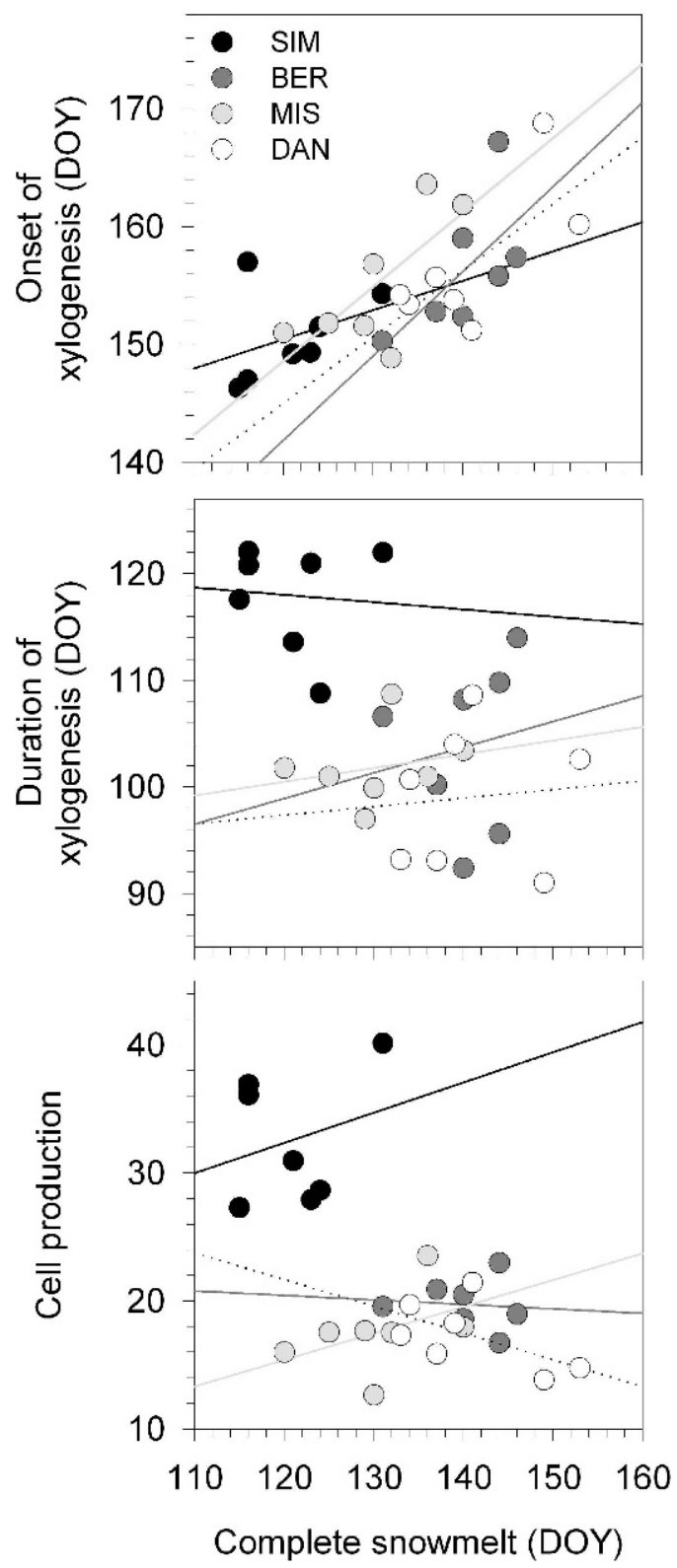

FIGURE 5. Between-years analysis showing the relationships of onset and duration of xylogenesis and cell production (number of cells along the tree ring) with the date of complete snowmelt during 2002-2008 in the four permanent plots of black spruce in Quebec, Canada.

production of cells to be differentiated in summer and longer durations of xylogenesis (Kujansuu et al., 2007; Rossi et al., 2008b; Lupi et al., 2010). Moreover, the low temperatures in early spring could prevent high rates of cell division from being achieved even if complete snowmelt has occurred (Deslauriers et al., 2003). Thus, no close relationship can be found between the dates of complete snowmelt and growth if the rate of cell division is not taken into account.

The analysis based on spatial variability represented the longterm situation, considering the consequences of persistent spatial differences in the dates of complete snowmelt (Jonas et al., 2008). These findings confirmed the evidence of the well-known gradual reduction in length of the growing season and wood production at increasing altitudes and latitudes (Moser et al., 2010; Rossi et al., 2010; Rossi et al., 2011), where the climatic conditions radically affect decomposition of soil organic matter and mineralization of soil nutrients, which modifies the availability of nutrients for trees (Jarvis and Linder, 2000). Therefore, in the long term, the main direct constraints to growth of boreal forests could be the capture of carbon and nutrients from the soil. Wintertime nutrient cycling and microbial processes are known to strongly affect the annual pattern of internal transfer of nutrients in plants of cold ecosystems (Grogan and Jonasson, 2003; Groffman et al., 2009). So, despite the close relationship between the date of complete snowmelt and springtime resumption of cambial growth, our findings support the hypothesis of a determinant role of nutrient availability in the biomass production of the boreal forest.

Although at short time scale (temporal variability), the results contrasted with the hypothesis that late snowmelts decrease cell production; there is no discrepancy with the model proposed by Vaganov et al. (1999). That model covered a study period of 50 years and meteorological records of the last century, which can be considered as representing long-term climatic conditions. Our findings demonstrate that, on a short time scale (e.g. at inter-annual scale), early thawing is closely correlated with an earlier cambial resumption but cannot explain a higher cell production and duration of xylogenesis, which could require more profound modifications, such as those related to the nutrient cycling of the soil.

\section{Acknowledgments}

This work was funded by Consortium de Recherche sur la Forêt Boréale Commerciale and Fonds de Recherche sur la Nature et les Technologies du Québec. The authors thank B. Dufour, G. Dumont-Frenette, F. Gionest, C. Lupi, S. Pedneault, P.-Y. Plourde, G. Savard, and M. Thibeault-Martel for technical support; L. Trainotti for the hospitality offered during manuscript preparation; M. Hughes for his recommendations on the manuscript; and A. Garside for checking the English text.

\section{References Cited}

Abe, H., Funada, R., Ohtani, J., and Fukazawa, K., 1997: Changes in the arrangement of cellulose microfibrils associated with the cessation of cell expansion in tracheids. Trees, 11: $328-332$.

Bergh, J., and Linder, S., 1999: Effects of soil warming during spring on photosynthetic recovery in boreal Norway spruce stands. Global Change Biology, 5: 245-253.

Bergh, J., Linder, S., Lundmark, T., and Elfving, B., 1999: The effect of water and nutrient availability on the productivity of Norway spruce in northern and southern Sweden. Forest Ecology and Management, 119: 51-62.

Cairns, D. M., and Malanson, G. P., 1998: Environmental variables influencing the carbon balance at the alpine treeline: a modeling approach. Journal of Vegetation Science, 9: 679-692.

Chen, W. J., Black, T. A., Yang, P. C., Barr, A. G., Neumann, H. H., Nesic, Z., Blanken, P. D., Novak, M. D., Eley, J., Ketler, R. J., and Cuenca, R., 1999: Effects of climatic variability on the annual carbon sequestration by a boreal aspen forest. Global Change Biology, 1999: 41-53.

Decker, K. L. M., Wang, D., Waite, C., and Scherbatskoy, T., 2003: Snow removal and ambient air temperature effects on forest soil temperatures in northern Vermont. Soil Science Society of America Journal, 67: 1234-1243.

Deslauriers, A., and Morin, H., 2005: Intra-annual tracheid production in balsam fir stems and the effect of meteorological variables. Trees, 19: 402-408.

Deslauriers, A., Morin, H., and Begin, Y., 2003: Cellular phenology of annual ring formation of Abies balsamea in the Quebec boreal forest (Canada). Canadian Journal of Forest Research, 33: 190-200. 
Deslauriers, A., Rossi, S., Anfodillo, T., and Saracino, A., 2008: Cambium phenology, wood formation and temperature thresholds in two contrasting years at high altitude in southern Italy. Tree Physiology, 28: 863-871.

Forster, T., Schweingruber, F. H., and Denneler, B., 2000: Increment puncher: a tool for extracting small cores of wood and bark from living trees. IAWA Journal, 21: 169-180.

Goodine, G. K., Lavigne, M. B., and Krasowski, M. J., 2008: Springtime resumption of photosynthesis in balsam fir (Abies balsamea). Tree Physiology, 28: 1069-1076.

Graumlich, L. J., and Brubaker, L. B., 1986: Reconstruction of annual temperature (1590-1979) for Longmire, Washington, derived from tree-rings. Quaternary Research, 25: 223-234.

Gričar, J., Čufar, K., Oven, P., and Schmitt, U., 2005: Differentiation of terminal latewood tracheids in silver fir trees during autumn. Annals of Botany, 95: 959-965.

Gričar, J., Zupančič, M., Cufar, K., Koch, G., Schmitt, U., and Oven, P., 2006: Effect of local heating and cooling on cambial activity and cell differentiation in the stem of Norway spruce (Picea abies). Annals of Botany, 97: 943-951.

Groffman, P. M., Hardy, J. P., Fisk, M. C., Fahey, T. J., and Driscoll, C. T., 2009: Climate variation and soil carbon and nitrogen cycling processes in a northern hardwood forest. Ecosystems, 12: 927-943.

Grogan, P., and Jonasson, S., 2003: Controls on annual nitrogen cycling in the understory of a subarctic birch forest. Ecology, 84: 202-218.

Jarvis, P., and Linder, S., 2000: Constraints to growth of boreal forests. Nature, 405: 904-905.

Jonas, T., Rixen, C., Sturm, M., and Stoeckli, V., 2008: How alpine plant growth is linked to snow cover and climate variability. Journal of Geophysical Research, 113: article G03013.

Körner, C., 2003a: Alpine Plant Life: Functional Plant Ecology of High Mountain Ecosystems. Berlin: Springer-Verlag.

Körner, C., 2003b: Carbon limitation in trees. Journal of Ecology, 91: 4-17.

Körner, C., and Hoch, G., 2006: A test of treeline theory on a montane permafrost island. Arctic, Antarctic, and Alpine Research, 38: 113-119.

Körner, C., and Paulsen, J., 2004: A world-wide study of high altitude treeline temperatures. Journal of Biogeography, 31: 713-732.

Kujansuu, J., Yasue, K., Koike, T., Abaimov, A. P., Kajimoto, T., Takeda, T., Tokumoto, M., and Matsuura, Y., 2007: Climatic responses of tree-ring widths of Larix gmelinii on contrasting north-facing and south-facing slopes in central Siberia. Journal of Wood Science, 53: 87-93.

Lupi, C., Morin, H., Deslauriers, A., and Rossi, S., 2010: Xylem phenology and wood production: resolving the chicken-or-egg dilemma. Plant Cell and Environment, 33: 1721-1730.

McMillan, A. M., Winston, G. C., and Goulden, M. L., 2008: Age-dependent response of boreal forest to temperature and rainfall variability. Global Change Biology, 14: 1904-1916.

Menzel, A., Sparks, T. H., Estrella, N., Koch, E., Aasa, A., Ahas, R., Alm-Kübler, K., Bissolli, P., Braslavská, O., Briede, A., Chmielewski, F. M., Crepinsek, Z., Curnel, Y., Dahl, Å., Defila, C., Donnelly, A., Filella, Y., Jatczak, K., MåGe, F., Mestre, A., Nordli, Ø., Peñuelas, J., Pirinen, P., Remišová, V., Scheifinger, H., Striz, M., Susnik, A., Van Vliet, A. J. H., Wielgolaski, F.-E., Zach, S., and Zust, A., 2006: European phenological response to climate change matches the warming pattern. Global Change Biology, 12: 1969-1976.
Moser, L., Fonti, P., Buentgen, U., Franzen, J., Esper, J., Luterbacher, J., and Frank, D., 2010: Timing and duration of European larch growing season along altitudinal gradients in the Swiss Alps. Tree Physiology, 30: 225-233.

Oribe, Y., Funada, R., Shibagaki, M., and Kubo, T., 2001: Cambial reactivation in locally heated stems of the evergreen conifer Abies sachalinensis (Schmidt) Masters. Planta, 212: 684-691.

Oribe, Y., Funada, R., and Kubo, T., 2003: Relationships between cambial activity, cell differentiation and the localisation of starch in storage tissues around the cambium in locally heated stems of Abies sachalinensis (Schmidt) Masters. Trees, 17: 185-192.

Rossi, S., Anfodillo, T., and Menardi, R., 2006a: Trephor: a new tool for sampling microcores from tree stems. IAWA Journal, 27: 89-97.

Rossi, S., Deslauriers, A., and Anfodillo, T., 2006b: Assessment of cambial activity and xylogenesis by microsampling tree species: an example at the alpine timberline. IAWA Journal, 27: 383-394.

Rossi, S., Deslauriers, A., Anfodillo, T., and Carraro, V., 2007: Evidence of threshold temperatures for xylogenesis in conifers at high altitude. Oecologia, 152: 1-12.

Rossi, S., Deslauriers, A., Anfodillo, T., and Carrer, M., 2008a: Age-dependent xylogenesis in timberline conifers. New Phytologist, 177: 199-208.

Rossi, S., Deslauriers, A., Gričar, J., Seo, J.-W., Rathgeber, C. B. K., Anfodillo, T., Morin, H., Levanic, T., Oven, P., and Jalkanen, R., 2008b: Critical temperatures for xylogenesis in conifers of cold climates. Global Ecology and Biogeography, 17: 696-707.

Rossi, S., Morin, H., and Tremblay, M.-J., 2010: Growth and productivity of black spruce (Picea mariana) belonging to the first cohort in stands within and north of the commercial forest in Quebec, Canada. Annals of Forest Science, 67: 807.

Rossi, S., Morin, H., Deslauriers, A., and Plourde, P.-Y., 2011: Predicting xylem phenology in black spruce under climate warming. Global Change Biology, 17: 614-625.

Serreze, M. C., Walsh, J. E., Chapin, F. S., III, Osterkamp, T., Dyurgerov, M., Romanovsky, V., Oechel, W. C., Morison, J., Zhang, T., and Barry, R. G., 2000: Observational evidence of recent change in the northern high-latitude environment. Climatic Change, 46: 159-207.

Thibeault-Martel, M., Krause, C., Morin, H., and Rossi, S., 2008: Cambial activity and intra-annual xylem formation in roots and stems of Abies balsamea and Picea mariana. Annals of Botany, 102: 667-674.

Turcotte, A., Morin, H., Krause, C., Deslauriers, A., and Thibeault-Martel, M., 2009: The timing of spring rehydration and its relation with the onset of wood formation in black spruce. Agricultural and Forest Meteorology, 149: 1403-1409.

Vaganov, E. A., Hughes, M. K., Kirdyanov, A. V., Schweingruber, F. H., and Silkin, P. P., 1999: Influence of snowfall and melt timing on tree growth in subarctic Eurasia. Nature, 400: 149-151.

Zhang, X., Vincent, L. A., Hogg, W. D., and Niitsoo, A., 2000: Temperature and precipitation trends in Canada during the 20th century. Atmosphere Ocean, 38: 395-429. 